$\xi_{p}$

\title{
Social policy and social legislation A jurisprudential interface
}

\author{
Prof. Dr. Shefali Raizada * \\ Amity Law School Amity University, U.P.India \\ *Corresponding author E-mail:
}

\begin{abstract}
Principle of democracy as governance is for the people by the people and of the people. People are not the recipient of state framed policies and programs. Citizens are not only consumers, choosers or users, but active participants for making and shaping the policies. According to Duguit, "Essence of law is to serve and secure social solidarity, where individual has to perform obligations as a member of the community". Duguit says "everyone has to perform his duties to the society which would help to develop cooperation and social solidarity." Law and society are interrelated and interdependent. Changes in every social component leads to change in various aspects, right from the social institutions, customs, ideologies, human behavior and human interactions.

Law is meant for nonprofessionals. The welfare of the society \&humanity is the sole purpose of Indian constitution. To take care of interests, social security, social solidarity are the main aim of law. Sociological school of thought says that 'Law is social phenomenon'. According to this school, essential characteristic of law should be to represent common interaction of men in social group. Treatment towards law should be as instrument of social control and social progress. The role of law and its functioning towards society is the basic philosophy of sociological jurisprudence.

Thus, social progress is very much regulated by the degree of law. Law is like the steering to lead society in particular direction. Law may be the fulcrum to control society. Balance between law and society will certainly responsible for social progress.
\end{abstract}

Keywords: Democracy; Social Institutions; Social Solidarity; Law.

\section{Introduction}

In legal Theory and Jurisprudence Sevigny firmly believed that "law is a product of general consciousness or will of the people and manifestation of their spirit." It consists of tradition, customs habits and practices and beliefs of the people. Even law develops with people, time and needs of the community. Rousseau in his 'Social Contract' theory pointed out that people wanted their rights of freedom and equality be protected which can be surrendered not to a single individual ie. Sovereign, but to the community as a whole. Therefore 'General Will' of the people becomes prominent and deciding factor. He said that if government and laws are not in the conformity to 'general will' they might be discarded.

Another approach to this theory is of Hart as also emphasized the relationship between law and society. According to him, morality is a necessary condition of society and it is the duty of law to keep morality intact to save society.

The great jurist Henry Maine believes in the historical method for understanding of law and also of the opinion that law evolves from the situations and circumstances, but also acknowledge the relationship between law and society and also pointed out that law must follow the pace according to the changing needs of the society.

Savigny gave the theory of VOLSGEIST-as a source of law where he propounded that law is the product of general consciousness or will of the people. John Lock opined that the purpose of law is to protect the rights of men and so long as these laws are protected by state, its laws are valid.

Exponents of Sociological school believe that law is social phenomenon. They emphasized on the focus of law be on the social progress .Roscoe Pound said, "Sociological jurists look more for the working of law than for its abstract content". No belief on the mechanical application of law but to take hold of societal experiences and control. Roscoe Pound conceived law as a 'social engineering' as the main task to process the social ordering and to avoid all conflicts.

As per the concept of latest American Realist School of Jurisprudence, it's pedagogy of study of law to investigate social factors making base of legislation. Emphasis of Realist school is on the court functioning. They pointed out that interpretation is rather important than the legislation. Courts may do more in the application of law rather extracting logics from general rules. According to this school, judges play important role in laying down the laws. They interpret the traditions, customs and confirm the laws. Judges' interpretation of law is the final form of the law. In this way it can be said that judicial pronouncements of law are the true subject matter of jurisprudence where the social wellbeing is the sole concern.

In continuation of this jurisprudential background Indian constitution was also drafted with the objective of welfare of the society. In one way it may be called as predominantly a social document, aiming social welfare with all equality and equity. True spirit of constitution is to ensure justice-social, economic and political- to each and every citizen of India.

Traditionally law is the collection of rules. Concept of justice is considered as inbuilt within law. Justice means-legislation serving the public and in this way, there is a need for more active judiciary and creative legislature for the fulfilment of public wellbeing and aspirations. It is well known that democratic traits evolve from natural law where all values, customs and traditions are incorporated. In this way democratic law may be the most stable order of its kind. When democratic elements are emanated from values and 
traditions, it is very much close to social institutions and public domain.it is important for lawmakers and law administrators to have full understanding of social ideas, social practices and social environment. In concern of social legislation every part of the society needs to be examined, as law cannot be confined to confined walls. It should have wide spectrum.

Scandinavian Realist School says that legislation is not separate, but it is a judge made law. It is the law with the purpose of achieving the peaceful co-existence in its best possible manner. Legal activities are indispensable for the existence of society. They are the guiding principles of social welfare.

Therefore law is the guiding source to society and it revolves around various social activities and institutions. Law becomes prominent in following the social pattern and social behavior. When the sole aim of law is to protect the citizens means protection of their rights. Laws should be for the benefit of common man and in this way social legislation should be as per the needs of the society.

In broad theoretical sense these all jurisprudential approaches have given different angles of development of law but one thing is common as all of them have cleared the strong relationship between Law and society. The word very appropriately used here is' social legislation', which is self-explanatory and essence of legal order. It is clearly showing that legislation should be done as per the needs of society and society should be strictly adhered to law. And in these way only social institutions, social ideologies, social relationships and social interests can be well protected.

It is very much clear that study of law should be in relation to society. They are the social circumstances which give birth legal institutions. Legal order is as tool for social control and it works vice versa with same degree. Thus, there may be alterations in social conditions, values and attitudes but within the pretext of law and order of the day and law has to be proved as highly effective device for producing the social change. Legislation and legal order should be reasonable in the protection of rights. Social interests are the strong factors influencing the creation of law. Balancing between instrument of law and social order is essential to pave the way for social development and social justice in the country.

\section{References}

[1] Gangrade, K.D. (1978), Social Legislation in India, Concept Publishing Company, New Delhi. The Planning Social Legislation: It's Role in Social Commission Welfare, (1956) Government of India, and Delhi.

[2] Bose, A.B. Social Welfare Planning in India, U.N. pub, Bangkok Choudry,

[3] Paul Hand book on social welfare in India, streling pub, New Delhi, 1979

[4] Choudry, Paul Social Welfare Administration, Atma Ram \& Sons, Delhi, 1979.

[5] Dennison.D \& Chepman, Valeries Social policy and Administration, George A and Unwin, London.

[6] Dubey S.N. Administration of social welfare programmes in India,

[7] Somaiya pub, Bombay. Dbey S.N. \& Murdia Administration of policy and programmes for backward classess in India, Somaiya pub, Bombay.

[8] Gangrade, K.D Social legislation in India Vol.I\&II Jacob K.K. Social policy in India

[9] Jagadeesan.P. Marriage and Social legislations in Tamil Nadu, Elachiapen Pub, Chennai, 1990. Shunmugavelayutham K. Social Legislations and Social Change, Valga Valamudan pub, Chennai, 1998.

[10] Paras Diwan, Administative law (Allahabad Law Agency)2004 P.124

[11] J.N.Pandey,Constitutional Law of Inda(Allahabad Law Agency) 2008 P.386

[12] Vinay Kumar Malhotra,Welfare State and Supreme Court of India(Delhi ,Deep and deep Publications)p. 269

[13] Kulkarni P.D. Social Policy in India. Bombay: Tata Institute of Social Sciences.

[14] Government of India Publications: Social Legislations.

[15] Gangrade, K.D. Social Legislations, Vols I \& II. New Delhi: Concept Publications.
[16] Chatterjee, B.B. Impact of Social Legislation on Social Change. Calcutta, Minerva Association.

[17] Dennison, D. and Valeris Chapman. Social Policy and Administration. London, George Allen and Unwin.

[18] Planning Commission. Social Legislation in India.

[19] Constitution of India \& Relevant Bare Acts. 